\title{
Article \\ Phosphorus Fertilization Enhances Productivity of Forage Corn (Zea mays L.) Irrigated with Saline Water
}

\author{
Hamza Bouras ${ }^{1}{ }^{(0}$, Ahmed Bouaziz $^{1}$, Redouane Choukr-Allah ${ }^{1}$, Abdelaziz Hirich ${ }^{2, *}$, Krishna Prasad Devkota $^{2}$ \\ and Bassou Bouazzama ${ }^{3}$ \\ 1 Department of Crop Production, Protection and Biotechnology, Hassan II Institute of Agronomy and \\ Veterinary Medicine, Rabat 10101, Morocco; bourashamza07@gmail.com (H.B.); \\ hmadbouaziz@gmail.com (A.B.); redouane53@yahoo.fr (R.C.-A.) \\ 2 African Sustainable Agriculture Research Institute (ASARI), Mohammed VI Polytechnic University (UM6P), \\ Laayoune 70000, Morocco; krishna.devkota@um6p.ma \\ 3 National Institute for Agricultural Research (INRA), Beni Mellal 23020, Morocco; \\ bassoubouazzama@gmail.com \\ * Correspondence: abdelaziz.hirich@um6p.ma; Tel.: +21-266-617-1546
}

Citation: Bouras, H.; Bouaziz, A.; Choukr-Allah, R.; Hirich, A.; Devkota, K.P.; Bouazzama, B. Phosphorus Fertilization Enhances Productivity of Forage Corn (Zea mays L.) Irrigated with Saline Water. Plants 2021, 10 2608. https://doi.org/10.3390/ plants10122608

Academic Editor: Eugenio Cazzato

Received: 21 October 2021

Accepted: 24 November 2021

Published: 28 November 2021

Publisher's Note: MDPI stays neutral with regard to jurisdictional claims in published maps and institutional affiliations.

Copyright: (c) 2021 by the authors. Licensee MDPI, Basel, Switzerland. This article is an open access article distributed under the terms and conditions of the Creative Commons Attribution (CC BY) license (https:// creativecommons.org/licenses/by/ $4.0 /)$.

\begin{abstract}
Salinity is a major problem affecting crop production in many regions in the world including Morocco. Agricultural practices such as fertilization could be useful to overcome this problem and improve crop productivity. The objective of our study was to evaluate the combined effect of phosphorus fertilization and irrigation water salinity on growth, yield, and stomatal conductance of forage corn (Zea mays L.) cv. "Sy sincerro". Field experiments were carried out for two years testing four levels of irrigation water salinity $\left(\mathrm{ECw}=0.7 ; 2,4\right.$, and $\left.6 \mathrm{dS} \cdot \mathrm{m}^{-1}\right)$ and three rates of phosphorus $\left(105,126\right.$, and $\left.150 \mathrm{~kg} \mathrm{P}_{2} \mathrm{O}_{5} \cdot \mathrm{ha}^{-1}\right)$ fertilization conducted in a split-plot design with three replications. The obtained results show that irrigation water salinity had a negative effect on all monitored parameters. For instance, the dry matter yield reduced by an average of 19.3 and 25.1\% compared to the control under saline irrigation with an EC value equal to 4 and $6 \mathrm{dS} \cdot \mathrm{m}^{-1}$, respectively. The finding also showed that phosphorus applications tend to increase root weight, root length, stem length, leaf stomatal conductance, grain yield and dry matter yield under salinity conditions. For example, the addition of phosphorus with a rate of 126 and $150 \mathrm{~kg} \mathrm{P}_{2} \mathrm{O}_{5} \cdot \mathrm{ha}^{-1}$ respectively improved dry matter yield by an average of 4 and $9 \%$ under low salinity level $\left(E C w=2 \mathrm{dS} \cdot \mathrm{m}^{-1}\right)$, by 4 and $15 \%$ under medium salinity $\left(4 \mathrm{dS} \cdot \mathrm{m}^{-1}\right)$, and by 6 and $8 \%$ under a high salinity level $\left(6 \mathrm{dS} \cdot \mathrm{m}^{-1}\right)$. Our finding suggests that supplementary $\mathrm{P}$ application could be one of the best practices to reduce the adverse effects of high salinity on growth and development of forage corn.
\end{abstract}

Keywords: irrigation; biomass yield; stomatal conductance; silage; best practices

\section{Introduction}

Salinity is a major constraint that limits crop production in many regions of the world. It is estimated that approximately $20 \%$ of cultivated land in the world and $33 \%$ of irrigated land, are salt-affected and degraded [1]. Soil salinity is increasing in many parts of the world and has become a serious economic and environmental constraint limiting agricultural productivity and profitability, reducing water and nutrient-use efficiencies, and causing land abandonment and desertification. It has been predicted that more than $50 \%$ of the arable land could be salinized by the year 2050 [2]. Salinization is the main cause of soil degradation in irrigated areas induced by several factors: arid climate, use of saline water for irrigation, poor drainage system, over-irrigation, and misuse of fertilizers and phytosanitary products.

Soil salinity is a major problem in the Mediterranean region where 27.3 million ha of soil have been salt-affected with 7.3 million ha in Morocco, Spain, Tunisia, and Turkey [3]. According to the Moroccan Department of Agriculture, soil salinization affects nearly 
500,000 ha and causes significant losses in agricultural productivity. Secondary salinization, which is the fastest form of soil degradation in irrigated areas, affects around 160,000 ha or around 16\% of irrigated land in Morocco [4]. The Tadla is one of the main irrigated saltaffected agricultural zones in Morocco, with a total arable land equal to 259,600 ha, where $49 \%$ is irrigated. According to ORMVAT [5], water salinity is highly variable around an overall average of $2.76 \mathrm{dS} \cdot \mathrm{m}^{-1}$ in the perimeter of Tadla. The highest electrical conductivity (EC) is found at Beni Amir perimeter with a maximum value of $8.4 \mathrm{dS} \cdot \mathrm{m}^{-1}$.

Salinity is a major abiotic stress that limits the growth and productivity of a wide variety of crop species across the world [6-8]. Increased salinity leads to a reduction in the plant biomass, leaf area, stem, and root length and ultimately crop yield [9]. Salinity causes three major stresses on the plant growth: (a) it increases osmotic pressure in the soil solution, which causes reduced water availability; (b) high concentration of toxic ions, especially sodium $(\mathrm{Na}+)$ and chloride (Cl-) in the soil solution that leads to increased accumulation of these ions in leaves; (c) it causes nutrient disorder and deficiency in plants [10]. Under saline conditions, plants cannot tolerate the toxic amounts of solutes in their cytoplasm. They either restrict a large amount of solutes in their vacuole or compartmentalize these toxic ions in tissues to support their normal metabolic activities [11]. Salt tolerance of a plant is controlled by several factors including soil, water, plant, and environmental conditions [12]. There are several mechanisms and strategies that enable plants to survive under salinity conditions including: ion vacuolation, accumulation of adaptive osmolytes, osmotic adaptation and adjustment, selective transport and uptake of ions, salt exclusion, ion homeostasis, and salt excretion in plant organs such as leaves [13].

Corn (Zea mays L.) is one of the three most important cereal crops (after wheat and rice) that can be grown in a wide range of climates [14]. Several early studies have evaluated the impact of salinity on maize, but only a few have reported the interactive effect of salinity and fertilization. For instance, Rhoades et al. [15] reported that maize yield reduced by $50 \%$ under soil salinity with an EC value of $5.9 \mathrm{dS} \cdot \mathrm{m}^{-1}$. They also reported that the salt tolerance threshold value of maize (beyond which yield reduction occurs) is $1.8 \mathrm{dS} \cdot \mathrm{m}^{-1}$ and maize is moderately sensitive to salinity. Other studies also found similar results, e.g., maize yield reduction by $0 \%$ at ECe $1.7 \mathrm{dS} \cdot \mathrm{m}^{-1}, 10 \%$ at $2.5 \mathrm{dS} \cdot \mathrm{m}^{-1}, 25 \%$ at $3.8 \mathrm{dS} \cdot \mathrm{m}^{-1}$, $50 \%$ at $6 \mathrm{dS} \cdot \mathrm{m}^{-1}$, and $100 \%$ at ECe $10 \mathrm{dS} \cdot \mathrm{m}^{-1}$ [16]. Irrigation with water salinity below $3 \mathrm{~g} \cdot \mathrm{L}^{-1}$ reduced maize yield by $10 \%$ compared with freshwater irrigation [17]. However, in the long-term even with the low concentrations of salt, a significant yield loss might occur due to salt accumulation of salt in the root zone. The annual average yield and crop water productivity of spring maize decreased by 5.3 and $2.6 \%$, respectively under saline irrigation water compared to freshwater irrigation [18].

The fertilizers supplied through irrigation water (fertigation) can reduce soil salinization and mitigate salinity stress impacts as it improves fertilizer use efficiency and nutrient availability [19]. In drip irrigation with fertilizer, the timing of application, fertilizer's concentration and rate can be easily controlled [1]. Phosphorus $(\mathrm{P})$ is the primary nutrient that restricts growth and development and ameliorates salt-induced reduction in crop yield [20]. Phosphorus fertilization in salt-affected soils improved crop growth and yield in 34 out of 37 crops studied, but did not increase the salt tolerance of crops [21]. Phosphate fertilization under saline conditions was shown to increase crop productivity. Such a beneficial effect generally involves a positive phosphorus-salinity interaction, especially when the salinity is moderate [21].

Phosphorus is a primary nutrient necessary for plant growth and development involved in many metabolic processes including energy transfer, signal transduction, biosynthesis of macromolecules, photosynthesis, and respiration [22]. Increasing P rate leads to increased salt tolerance of various crops such as sesame [23], tomato [24], micro-propagated potato [25], spinach [26], rice [27], pepper seedling [28], pistachio seedlings [29], barley [30], wheat [31], cucumber [32], wild (Hordeum maritimum) and cultivated barley (Hordeum vulgare) [33], common bean [34], green beans [35], and sugar beet [36]. Belouchrani et al. [37] reported that phosphorus application resulted in a remarkable improvement of sorghum 
growth and tolerance towards salinity, where it increased plant height, dry matter yield, nitrogen and phosphorus uptake, and accumulation of osmolytes such as proline. Malik et al. [38] reported that there is a synergistic relationship between phosphorus and other beneficial elements such as $\mathrm{K}^{+}, \mathrm{Ca}^{2+}$ and $\mathrm{Mg}^{2+}$, which stimulated an osmotic effect and therefore resulted in salt tolerance to some extent. Hence, the main objective of this study was to evaluate the interaction of phosphorus supply with different salinity of irrigation water and its effect on growth and productivity of forage corn (Zea mays L.) cv. "Sy Sincerro".

\section{Results}

\subsection{Analysis of Variance of Growth and Physiological Parameters}

Table 1 summarizes the results of the ANOVA (analysis of variance) of measured growth and physiological parameters as affected by irrigation water salinity and $P$ rates during 2019-2020. Salinity affected $(p<0.05)$ all parameters in both years except root fresh weight in both years. Phosphorus fertilization also affected $(p<0.05)$ most of the parameters except leaf number, plant height and leaf area in both years. The interaction effect was significant for shoot fresh weight and plant dry weight in 2019 and for plant dry weight, dry matter yield and grain yield in 2020 .

Table 1. Results of ANOVA (analysis of variance) for all investigated parameters during 2019-2020.

\begin{tabular}{|c|c|c|c|c|c|c|c|c|c|c|c|}
\hline Season & $\begin{array}{c}\text { Salinity and } \\
\text { P Rates }\end{array}$ & $\begin{array}{l}\text { Number } \\
\text { of Leaves }\end{array}$ & $\begin{array}{l}\text { Plant } \\
\text { Height }\end{array}$ & $\begin{array}{c}\text { Root } \\
\text { Length }\end{array}$ & $\begin{array}{l}\text { Root } \\
\text { Fresh } \\
\text { Weight }\end{array}$ & $\begin{array}{l}\text { Shoot } \\
\text { Fresh } \\
\text { Weight }\end{array}$ & $\begin{array}{c}\text { Plant } \\
\text { Dry } \\
\text { Weight }\end{array}$ & $\begin{array}{l}\text { Leaf } \\
\text { Area }\end{array}$ & $\begin{array}{c}\text { Stomatal } \\
\text { Conductance }\end{array}$ & $\begin{array}{c}\text { Dry } \\
\text { Matter } \\
\text { Yield }\end{array}$ & $\begin{array}{l}\text { Grain } \\
\text { Yield }\end{array}$ \\
\hline \multirow{3}{*}{2019} & Salinity & $0.04 *$ & $0.01 * *$ & $0.03 *$ & 0.10 & $0.05 *$ & $0.04 *$ & $0.01 * *$ & $0.02 *$ & $0.01^{* *}$ & $0.03 *$ \\
\hline & Phosphorus & 0.20 & 0.20 & $0.01^{* *}$ & 0.04 * & $0.03 *$ & $0.01 * *$ & 0.20 & $0.04 *$ & $0.04 *$ & 0.2 \\
\hline & Interaction & 0.40 & 0.60 & 0.07 & 0.15 & $0.02 *$ & $0.04 *$ & 0.40 & 0.2 & 0.2 & 0.3 \\
\hline \multirow{3}{*}{2020} & Salinity & $0.03 *$ & 0.02 & $0.01 * *$ & 0.30 & $0.04 *$ & $0.03 *$ & $0.02 *$ & $0.03 *$ & $0.03 *$ & 0.04 * \\
\hline & Phosphorus & 0.18 & 0.40 & $0.02 *$ & $0.01^{* *}$ & $0.02 *$ & $0.01 * *$ & 0.40 & $0.01 *$ & $0.04 *$ & $0.01 * *$ \\
\hline & Interaction & 0.30 & 0.30 & 0.12 & 0.70 & 0.09 & $0.01 * *$ & 0.60 & 0.13 & $0.005^{* *}$ & 0.015 * \\
\hline
\end{tabular}

${ }^{*}$ and ${ }^{* *}$ indicate significance level at $p=0.05$ and 0.01 , respectively.

\subsection{Growth Parameters}

Monitored plant growth parameters for both seasons are presented in Table 2. Under high salinity level $\left(6 \mathrm{dS} \cdot \mathrm{m}^{-1}\right)$ number of leaves, plant height, root fresh weight, shoot fresh weight, and leaf area showed an average reduction by $12-26 \%$. Conversely, root length increased by 16 and $12 \%$ under moderate $\left(4 \mathrm{dS} \cdot \mathrm{m}^{-1}\right)$ and high salinity $\left(6 \mathrm{dS} \cdot \mathrm{m}^{-1}\right)$, respectively (as an average of both seasons). Increasing $P$ fertilization under salinity conditions improved all growth parameters $(p \leq 0.05)$; the highest values of most parameters were obtained when the plant was supplied with $150 \mathrm{~kg} \mathrm{P}_{2} \mathrm{O}_{5} \cdot \mathrm{ha}^{-1}$ of $\mathrm{P}$ fertilization.

\subsection{Stomatal Conductance}

The combined data over two years showed that salinity has a reduced stomatal conductance (gs) by 30, 63 and $77 \%$ under saline irrigation with EC values 2, 4 and $6 \mathrm{dS} \cdot \mathrm{m}^{-1}$, respectively compared to control $\left(0.7 \mathrm{dS} \cdot \mathrm{m}^{-1}\right)$ (Figure 1$)$. It is obvious from the obtained results that increased $P$ fertilization significantly improved gs under saline conditions for both seasons. For example, an application of $150 \mathrm{~kg} \mathrm{P}_{2} \mathrm{O}_{5} \cdot \mathrm{ha}^{-1}$ resulted in an average increase in gs by 32,33 and $55 \%$ under 2,4 and $6 \mathrm{dS} \cdot \mathrm{m}^{-1}$, respectively compared to control. The results indicate that the gs improvement was greater under high salinity than under low salinity conditions. 
Table 2. Plant growth parameters under different irrigation water salinity and P rate. Values with the same letters under the same salinity level are statistically equal.

\begin{tabular}{|c|c|c|c|c|c|c|c|c|c|}
\hline Season & $\begin{array}{c}\text { Irrigation } \\
\text { Water } \\
\text { Salinity } \\
\left(d S \cdot m^{-1}\right)\end{array}$ & $\begin{array}{c}\text { P Rate } \\
\left(\mathrm{kg} \mathrm{P}_{2} \mathrm{O}_{5} \cdot \mathrm{ha}^{-1}\right)\end{array}$ & $\begin{array}{l}\text { Number of } \\
\text { Leaves }\end{array}$ & $\begin{array}{l}\text { Plant } \\
\text { Height } \\
\text { (cm) }\end{array}$ & $\begin{array}{l}\text { Root } \\
\text { Length } \\
\text { (cm) }\end{array}$ & $\begin{array}{c}\text { Root Fresh } \\
\text { Weight } \\
\left(g \cdot \text { plant }^{-1}\right)\end{array}$ & $\begin{array}{c}\text { Shoot } \\
\text { Fresh } \\
\text { Weight } \\
\left(\mathrm{g} \cdot \text { plant }^{-1}\right)\end{array}$ & $\begin{array}{c}\text { Plant Dry } \\
\text { Weight (g) }\end{array}$ & $\begin{array}{c}\text { Leaf Area } \\
\left(\mathrm{cm}^{2} \cdot \text { plant }^{-1}\right)\end{array}$ \\
\hline \multirow{12}{*}{ 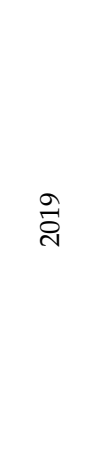 } & \multirow{3}{*}{0.7} & 105 & $13 \pm 2 \mathrm{a}$ & $165 \pm 15 b$ & $22 \pm 3 b$ & $22 \pm 4 b$ & $279 \pm 34 \mathrm{a}$ & $82 \pm 39 b$ & $25 \pm 6 b$ \\
\hline & & 126 & $14 \pm 2 \mathrm{a}$ & $181 \pm 8 \mathrm{a}$ & $21 \pm 4 b$ & $23 \pm 8 b$ & $282 \pm 60 \mathrm{a}$ & $87 \pm 61 \mathrm{~b}$ & $25 \pm 5 b$ \\
\hline & & 150 & $14 \pm 1 \mathrm{a}$ & $168 \pm 14 b$ & $22 \pm 6 a$ & $28 \pm 11 \mathrm{a}$ & $284 \pm 74 a$ & $119 \pm 43 a$ & $26 \pm 5 a$ \\
\hline & \multirow{3}{*}{2} & 105 & $11 \pm 2 c$ & $166 \pm 18 \mathrm{a}$ & $20 \pm 5 b$ & $30 \pm 9 b$ & $271 \pm 70 \mathrm{c}$ & $110 \pm 27 a$ & $24 \pm 6 b$ \\
\hline & & 126 & $12 \pm 2 b$ & $168 \pm 14 \mathrm{a}$ & $22 \pm 4 \mathrm{a}$ & $33 \pm 12 \mathrm{a}$ & $284 \pm 70 b$ & $102 \pm 45 \mathrm{a}$ & $25 \pm 5 b$ \\
\hline & & 150 & $12 \pm 2 \mathrm{a}$ & $166 \pm 18 \mathrm{a}$ & $21 \pm 3 b$ & $32 \pm 9 a$ & $292 \pm 77 a$ & $103 \pm 58 a$ & $28 \pm 4 a$ \\
\hline & \multirow{3}{*}{4} & 105 & $12 \pm 1 \mathrm{a}$ & $131 \pm 10 c$ & $22 \pm 3 b$ & $20 \pm 7 b$ & $209 \pm 37 b$ & $59 \pm 35 c$ & $19 \pm 3 c$ \\
\hline & & 126 & $12 \pm 1 \mathrm{a}$ & $153 \pm 12 \mathrm{a}$ & $25 \pm 3 a$ & $26 \pm 8 \mathrm{a}$ & $236 \pm 51 \mathrm{a}$ & $83 \pm 28 b$ & $22 \pm 5 b$ \\
\hline & & 150 & $13 \pm 1 \mathrm{a}$ & $147 \pm 12 b$ & $25 \pm 3 a$ & $27 \pm 8 a$ & $241 \pm 69 a$ & $97 \pm 43 a$ & $22 \pm 4 \mathrm{a}$ \\
\hline & \multirow{3}{*}{6} & 105 & $13 \pm 1 \mathrm{a}$ & $150 \pm 11 b$ & $24 \pm 6 b$ & $18 \pm 3 c$ & $200 \pm 29 b$ & $55 \pm 31 c$ & $19 \pm 4 b$ \\
\hline & & 126 & $13 \pm 1 \mathrm{a}$ & $148 \pm 6 b$ & $24 \pm 3 \mathrm{ab}$ & $19 \pm 3 b$ & $204 \pm 28 b$ & $76 \pm 17 b$ & $20 \pm 2 b$ \\
\hline & & 150 & $12 \pm 1 \mathrm{a}$ & $154 \pm 16 \mathrm{a}$ & $25 \pm 4 \mathrm{a}$ & $22 \pm 7 \mathrm{a}$ & $223 \pm 67 a$ & $81 \pm 35 a$ & $21 \pm 5 a$ \\
\hline \multirow{12}{*}{ હે } & \multirow{3}{*}{0.7} & 105 & $15 \pm 1 \mathrm{a}$ & $154 \pm 20 \mathrm{a}$ & $23 \pm 4 a$ & $22 \pm 4 b$ & $249 \pm 74 b$ & $97 \pm 5 b$ & $32 \pm 15 a$ \\
\hline & & 126 & $15 \pm 4 \mathrm{a}$ & $146 \pm 23 a$ & $22 \pm 5 \mathrm{a}$ & $24 \pm 8 b$ & $249 \pm 87 b$ & $95 \pm 4 b$ & $21 \pm 7 \mathrm{a}$ \\
\hline & & 150 & $14 \pm 3 \mathrm{a}$ & $137 \pm 28 \mathrm{a}$ & $24 \pm 8 \mathrm{a}$ & $25 \pm 11 \mathrm{a}$ & $276 \pm 80 \mathrm{a}$ & $113 \pm 7 \mathrm{a}$ & $24 \pm 8 \mathrm{a}$ \\
\hline & \multirow{3}{*}{2} & 105 & $12 \pm 3 a$ & $153 \pm 18 \mathrm{a}$ & $21 \pm 5 b$ & $32 \pm 9 b$ & $288 \pm 84 a$ & $116 \pm 5 a$ & $26 \pm 7 a$ \\
\hline & & 126 & $11 \pm 1 \mathrm{a}$ & $156 \pm 29 a$ & $21 \pm 4 b$ & $34 \pm 12 \mathrm{a}$ & $268 \pm 100 \mathrm{a}$ & $114 \pm 4 \mathrm{a}$ & $19 \pm 8 \mathrm{a}$ \\
\hline & & 150 & $13 \pm 4 \mathrm{a}$ & $163 \pm 24 \mathrm{a}$ & $22 \pm 4 \mathrm{a}$ & $33 \pm 15 a$ & $285 \pm 111 \mathrm{a}$ & $118 \pm 7 a$ & $26 \pm 9 a$ \\
\hline & \multirow{3}{*}{4} & 105 & $12 \pm 4 b$ & $134 \pm 14 b$ & $24 \pm 3 b$ & $22 \pm 7 b$ & $178 \pm 44 b$ & $74 \pm 11 b$ & $19 \pm 4 b$ \\
\hline & & 126 & $13 \pm 4 \mathrm{a}$ & $159 \pm 16 \mathrm{a}$ & $26 \pm 3 a$ & $26 \pm 8 \mathrm{a}$ & $266 \pm 65 a$ & $106 \pm 7 \mathrm{a}$ & $24 \pm 5 \mathrm{a}$ \\
\hline & & 150 & $13 \pm 2 \mathrm{a}$ & $152 \pm 24 \mathrm{a}$ & $24 \pm 4 \mathrm{a}$ & $26 \pm 8 a$ & $267 \pm 105 \mathrm{a}$ & $107 \pm 6 \mathrm{a}$ & $25 \pm 8 \mathrm{a}$ \\
\hline & \multirow{3}{*}{6} & 105 & $13 \pm 1 \mathrm{a}$ & $148 \pm 12 b$ & $23 \pm 6 b$ & $19 \pm 7 c$ & $169 \pm 40 c$ & $78 \pm 9 c$ & $18 \pm 4 c$ \\
\hline & & 126 & $12 \pm 2 \mathrm{a}$ & $152 \pm 6 \mathrm{ab}$ & $25 \pm 3 b$ & $23 \pm 3 a$ & $222 \pm 30 b$ & $90 \pm 4 b$ & $21 \pm 3 b$ \\
\hline & & 150 & $12 \pm 2 \mathrm{a}$ & $167 \pm 24 \mathrm{a}$ & $25 \pm 4 \mathrm{a}$ & $22 \pm 7 b$ & $251 \pm 82 \mathrm{a}$ & $97 \pm 4 \mathrm{a}$ & $22 \pm 6 \mathrm{a}$ \\
\hline
\end{tabular}

Small letters $(\mathrm{a}, \mathrm{b}$ and $\mathrm{c})$ indicate the statistically homogenous groups.

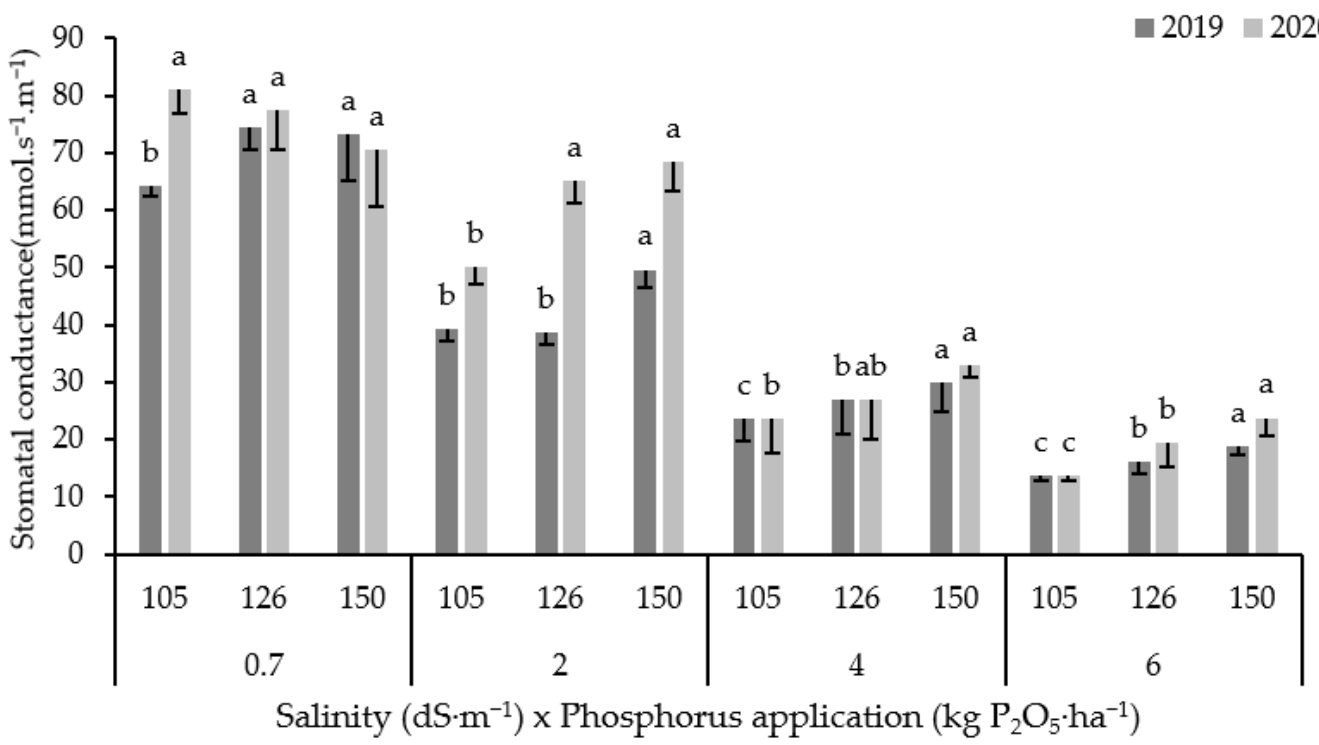

Figure 1. Variation in stomatal conductance for 2019 and 2020 seasons under different salinity levels and $\mathrm{P}$ rates. Error bars indicate the standard deviation. Phosphorus treatments under the same salinity level and for the same season without a common letter are significantly different at $p<0.05$. Small letters ( $a, b$ and $c)$ indicate the statistically homogenous groups.

\subsection{Dry Matter and Seed Yield}

Figure 2 illustrates the variation of dry matter yield influenced by both salinity and $P$ fertilization rates. As expected, salinity decreased dry matter yield and the average 
reduction rate (over two seasons) was equal to 2,17 and $23 \%$ compared to control under irrigation water salinity with an EC value equal to 2, 4 and $6 \mathrm{dS} \cdot \mathrm{m}^{-1}$, respectively. However, the dry matter yield responded positively to the increased $\mathrm{P}$ rate, and this improvement was more pronounced under salinity conditions compared to freshwater irrigation conditions. For example, under low salinity level $\left(2 \mathrm{dS} \cdot \mathrm{m}^{-1}\right)$ the application of 126 and $150 \mathrm{~kg} \mathrm{P}_{2} \mathrm{O}_{5} \cdot \mathrm{ha}^{-1}$ significantly increased dry matter yield by 4 and $9 \%$, respectively (averaged data over two seasons). While under moderate salinity $\left(4 \mathrm{dS} \cdot \mathrm{m}^{-1}\right.$ ), the increment rate was significant as it equaled to 4 and $15 \%$, respectively. Conversely, the application of 126 and $150 \mathrm{~kg} \mathrm{P}_{2} \mathrm{O}_{5} \cdot \mathrm{ha}^{-1}$ increased dry matter yield by 4 and $5 \%$, respectively under high level of salinity $\left(\mathrm{EC} 6 \mathrm{dS} \cdot \mathrm{m}^{-1}\right.$ ). The interaction between irrigation water salinity $\times \mathrm{P}$ rate was significant only for 2020, which indicates that grain yield responded differently to phosphorus application under high salinity irrigation water. In fact, grain yield was not affected by phosphorus application under freshwater irrigation $\left(0.7 \mathrm{dS} \cdot \mathrm{m}^{-1}\right)$; contrarily, it increased $(p<0.05)$ in high salinity level with increasing P rates.

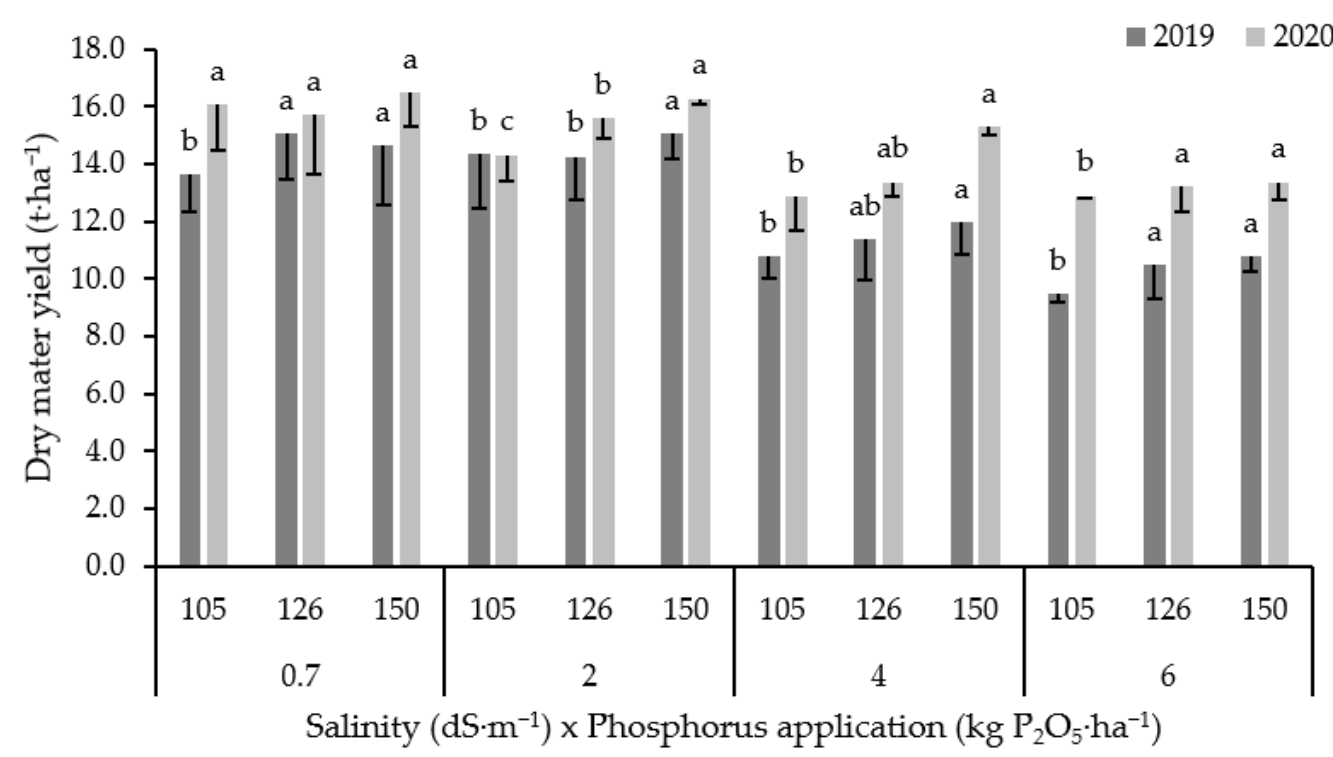

Figure 2. Variation in dry matter yield for both 2019 and 2020 seasons under different salinity levels and $\mathrm{P}$ rates. Error bars indicate the standard deviation. Phosphorus treatments under the same salinity level and for the same season without a common letter are significantly different at $p<0.05$. Small letters $(\mathrm{a}, \mathrm{b}$ and $\mathrm{c})$ indicate the statistically homogenous groups.

\subsection{Grain Yield}

Similarly to dry matter yield, grain yield of forage corn was significantly affected by salinity level and $P$ rate (Figure 3). The interaction between salinity $x P$ rate on grain yield was significant only for 2020 season. The results showed that grain yield responded differently to phosphorus application and was not affected by phosphorus application under low salinity level $\left(2 \mathrm{dS} \cdot \mathrm{m}^{-1}\right)$ contrarily to other salinity levels where the phosphorus effect was significant. Salinity caused a reduction in the grain yield by 5,19 and $26 \%$ (as an average of both seasons) compared to control under saline irrigation with an EC value equal to 2, 4 and $6 \mathrm{dS} \cdot \mathrm{m}^{-1}$, respectively. However, $\mathrm{P}$ fertilization helped the plant withstand salinity and improved grain yield $(p<0.05)$, especially under moderate $\left(4 \mathrm{dS} \cdot \mathrm{m}^{-1}\right)$ and high $\left(6 \mathrm{dS} \cdot \mathrm{m}^{-1}\right)$ salinity conditions. While under low salinity $\left(2 \mathrm{dS} \cdot \mathrm{m}^{-1}\right)$, grain yield was not affected $(p>0.05)$ by the $P$ rate. Grain yield increment rate when the crop was exposed to a $\mathrm{P}$ application of 126 and $150 \mathrm{~kg} \mathrm{P}_{2} \mathrm{O}_{5} \cdot \mathrm{ha}^{-1}$ was $11 \%$ under moderate salinity $\left(4 \mathrm{dS} \cdot \mathrm{m}^{-1}\right)$, and 3 and $15 \%$ under high salinity $\left(6 \mathrm{dS} \cdot \mathrm{m}^{-1}\right)$, respectively. 


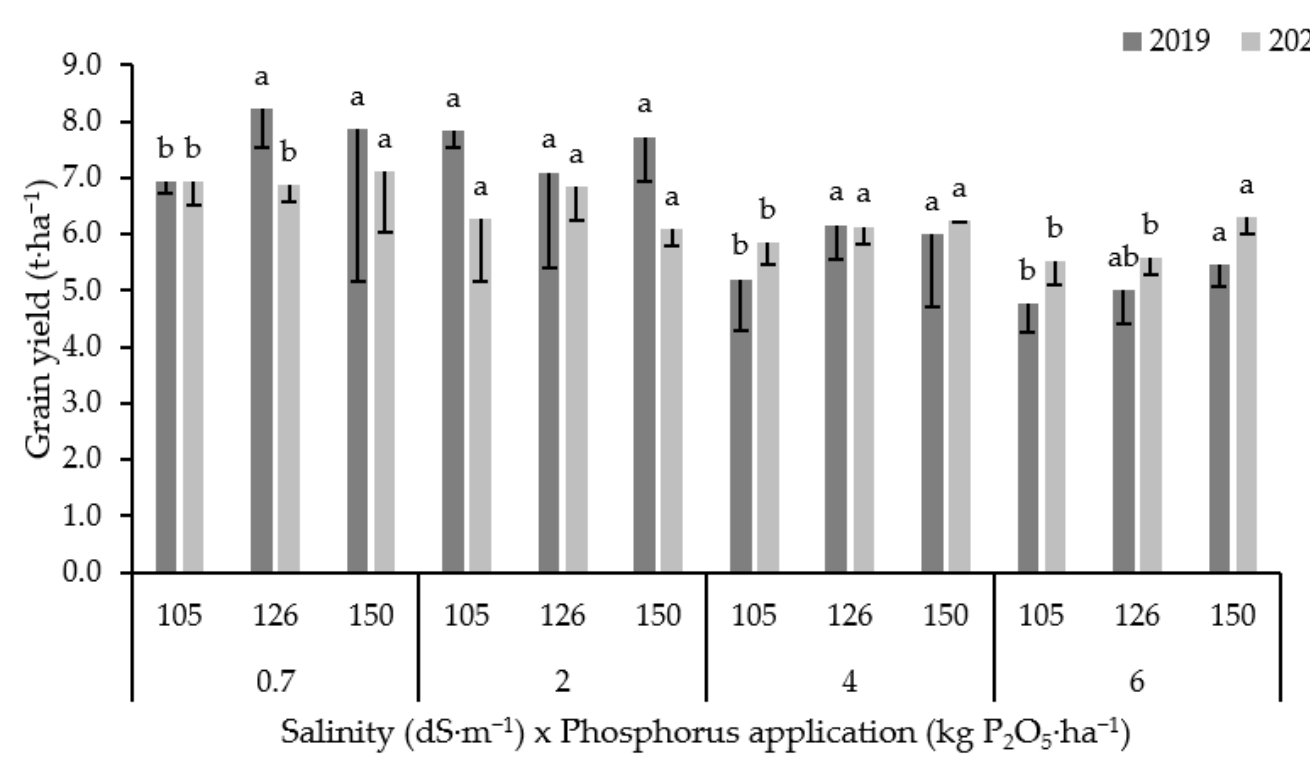

Figure 3. Variation in grain yield for both 2019 and 2020 seasons under different salinity levels and P rates. Error bars indicate the standard deviation. Phosphorus treatments under the same salinity level and for the same season without a common letter are significantly different at $p<0.05$. Small letters $(\mathrm{a}, \mathrm{b}$ and $\mathrm{c})$ indicate the statistically homogenous groups.

\subsection{Correlation Matrix}

Pearson's correlation analysis was conducted for the two growing seasons separately for all investigated agro-morphological parameters. The results obtained are shown in Figure 4. For the first trial season (Figure 4a), except for the root length parameter which had a significant positive correlation with salinity, a significant strong negative correlation was observed among most of the parameters and especially for shoot fresh weight, leaf area, stomatal conductance, dry matter yield, and grain yield. Results were confirmed during the second season (Figure $4 \mathrm{~b}$ ). The analysis also revealed a positive and moderate correlation of root, shoot and plant dry weight with the phosphorus application.

\subsection{Principal Component Analysis (PCA)}

Figure 5 displays the correlation circle of the investigated variables for each cropping season. The quality of the representation of the variables was assessed by the squared cosine. Results of PCA indicate that the first two principal components represent $82.5 \%$ and $63.2 \%$ of the data variability respectively for the first (Figure 5a) and the second season (Figure 5b). PC1 axis was explained by shoot fresh weight, dry matter yield, stomatal conductance, and plant dry weight, while the number of leaves is the main variable that contributed to the formation of the PC 2 axis. The projection of supplementary dependent variables showed that the salinity was correlated negatively with all PC1 variables. Moreover, root fresh weight is positively correlated with the phosphorus rate applied. 
(a)

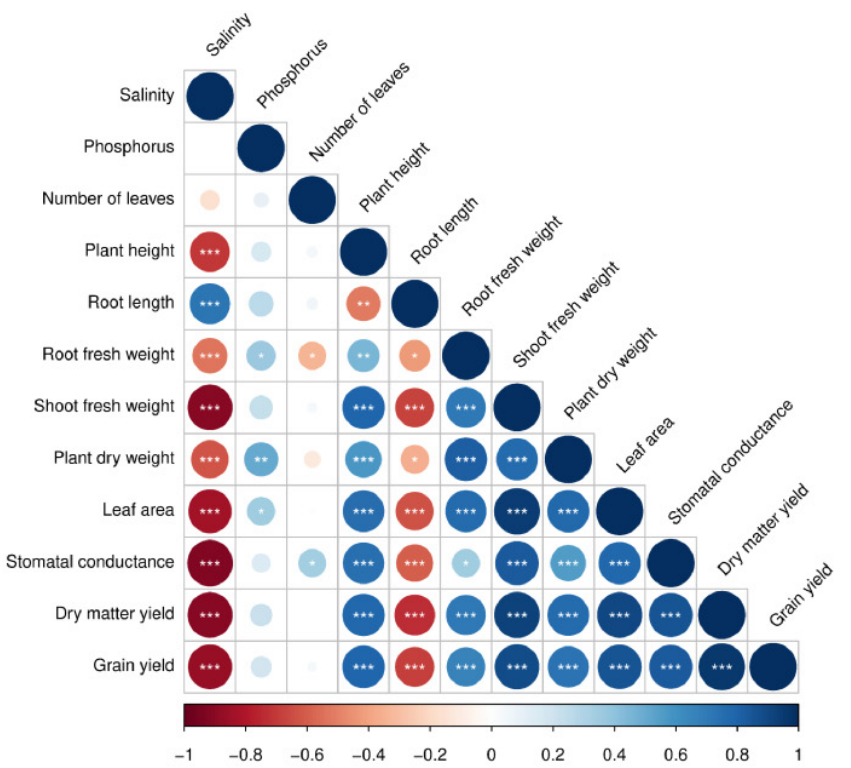

(b)

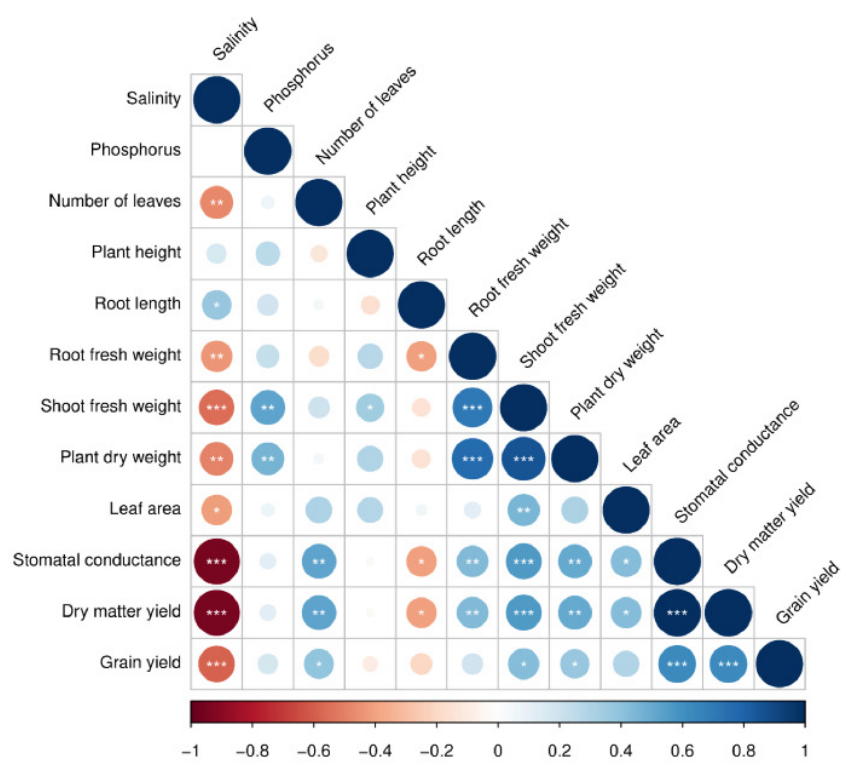

Figure 4. Pearson's correlation matrix for all the investigated parameters during 2019 (a) and 2020 (b) ${ }^{*}, * *, * * *$ indicates significance level at $p=0.05,0.01,0.001$ respectively. Color gradient corresponds to the Pearson coefficient of correlation.

(a)

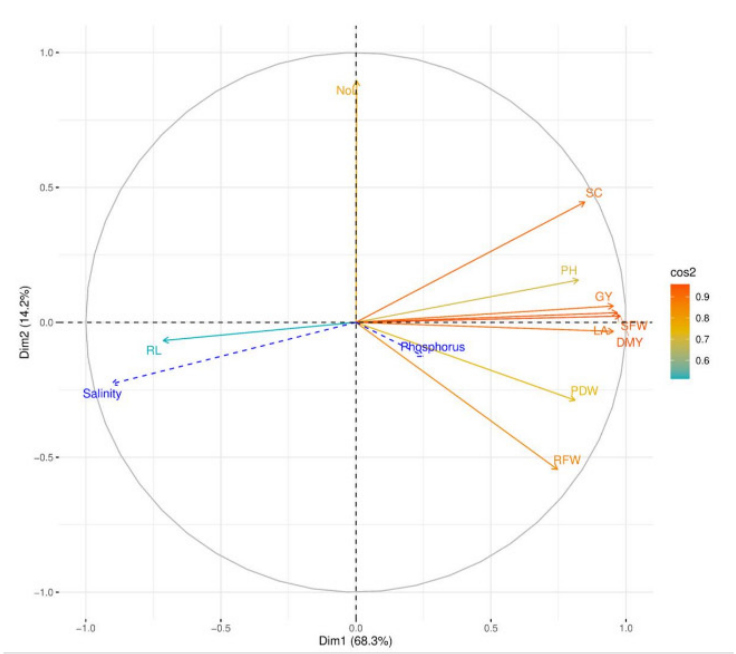

(b)

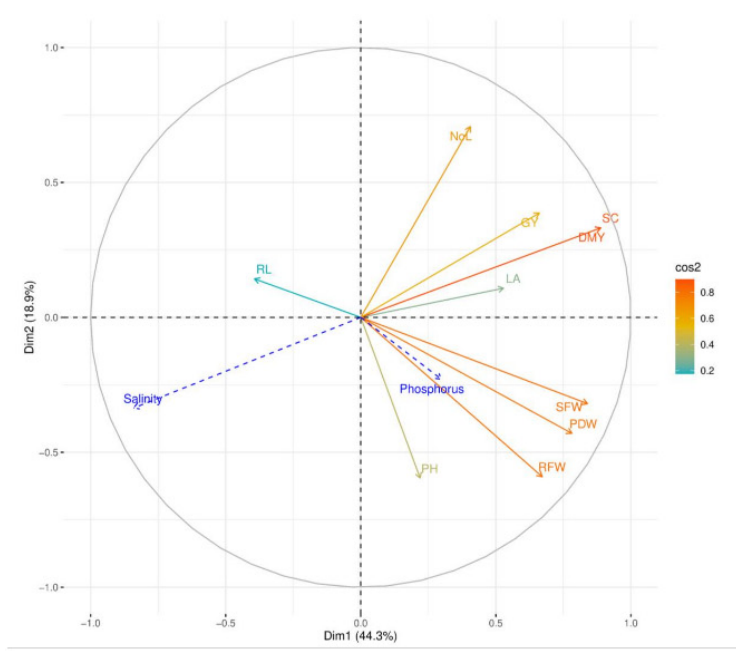

Figure 5. Correlation circle of variables on the principal two components for all investigated parameters during 2019 (a) and 2020 (b). NoL: Number of leaves, PH: Plant height, RL: Root length, RFW: Root fresh weight, SFW: Shoot fresh weight, PDW: Plant dry weight, LA: Leaf area, SC: Stomatal conductance, DMY: Dry matter yield, GY: Grain yield. Color gradient corresponds the quality of representation of the variables using the $\cos ^{2}$ of its coordinates. Blue arrows show the projection of the supplementary dependent variables.

\section{Discussion}

\subsection{Effect of Salinity on Plant Growth and Yield}

All growth and yield parameters of forage maize were affected in varying degrees depending on salinity level and applied phosphorous rate. Yield reduction under salinity is mainly explained by the reduction in photosynthetic activity. This study found that stomatal conductance consistently decreased when corn plants were exposed to high salinity (Figure 1). Soil salinity affects photosynthesis and thus the grain yield by reducing 
stomatal conductance [39]. The reduction in stomatal conductance reduces the photosynthetic rate and water uptake [40]. Salinity reduces photosynthetic activities in many ways, for example by inhibiting photosystem II [41], downregulating photosynthesis by stomatal closure, reducing photochemical and carbon metabolism [42], injuring chloroplast and stomata structure [43], and reducing chlorophyll and carotenoid content [44]. Our finding is consistent with previous findings in summer maize [45], bean and cotton [46], wheat [47], and grapevine [48], where soil salinity decreased photosynthetic rate, crop growth, and yield.

The lower yield under saline conditions can be explained by the reduced plant height and leaf area (Table 2). Salinity stress reduces average grain weight and grain number per cob as it limits sink size and reduces the enzyme invertase activity [49]. The low yield under salinity stress might be due to the reduction of translocation of assimilates, which consequently causes poor grain filling [50]. Moreover, salinity stress reduced grain weight and number by affecting osmotic processes, causing ion toxicity or $\mathrm{Na}^{+}$toxicity [51-53].

Saline water irrigation caused a significant reduction in growth parameters such as shoot length, fresh and dry weights of the shoot, leaf number per plant, and leaf area. In addition to the disturbance in physiological and metabolic processes, salinity stress reduced root development by reducing nutrient and water uptake through increasing soil osmotic potential [30]. Our results are consistent with the finding of Hussein et al. [54] who reported that salinity reduced stem, leaf, and whole plant dry weights in maize. In maize, salinity stress decreases the leaf area [55]; decreases biomass accumulation [54,56], stem and root length, and grain yield [9]. Leaf growth rate rapidly reduces under salinity stress due to a reduction in photosynthetic activity [56] and cell elongation [57]. The deleterious effect of salinity stress can happen from the combination of water stress, ion toxicities, ion imbalance, or a combination of all these factors [58]. Regarding root length, our study found no effect of salinity on the root length of maize; this seems to contradict the results reported by $[55,59]$ in maize and sugar beet.

\subsection{Effect of Phosphorus on Plant Growth and Yield}

Phosphorus fertilization significantly increased dry matter and grain yield under both saline and non-saline conditions. However, the positive effect of phosphorus was more pronounced under saline conditions (Figure 2), indicating $\mathrm{P}$ application as a risk minimization strategy under medium and high salinity conditions. Consistent with our results, P fertilization improved the above and below-ground dry weight and yield of barley by increasing crop tolerance against salinity $[30,60]$. Phosphorus application mitigates partially the adverse effects of salinity on maize [51], mung bean [61], green bean [35], chickpea [62], and wheat [31]. The increased crop yield under high salinity irrigation water can be attributed to the role of $\mathrm{P}$, which increased concentration and uptake of essential plant nutrients such as $\mathrm{N}$, and decreased the concentration and uptake of toxic ions. The improvement of the yield of crops by P supply in saline conditions is justified by an increase in plant height, nitrogen, and phosphorus uptake [37].

Phosphorus application increased parameters of growth and yield attributes such as leaf number, plant height, root length, root and shoot weight, and leaf area of maize; this increase was more pronounced in the high levels of $\mathrm{P}\left(150 \mathrm{~kg} \mathrm{P}_{2} \mathrm{O}_{5} \cdot \mathrm{ha}^{-1}\right)$ (Table 2). Its application under saline conditions reduced the adverse effect of salt stress in many crops [31,33,35,37,61-63]. This improvement in crop tolerance to salinity can be explained by the increase in $\mathrm{P}$ availability in soil, which indirectly improved absorption of $\mathrm{Ca}^{2+}$ and $\mathrm{Mn}^{+}$or $\mathrm{Mn}^{2+}$ as a result of reduced sodium absorption by the plant [64]. Moreover, $\mathrm{P}$ application enhances the synergistic relationship between $\mathrm{P}$ and other beneficial elements like $\mathrm{K}^{+}, \mathrm{Ca}^{2+}$ and $\mathrm{Mg}^{2+}$ and toxic ions which balances osmotic equilibrium and enhances salt tolerance to some extent [38]. Similar to this result, under saline conditions, P fertilization decreased sodium content in barley [60] and maintained the equilibrium between beneficial $\left(\mathrm{K}^{+}\right.$and $\left.\mathrm{Ca}^{2+}\right)$ and toxic ion $\left(\mathrm{Na}^{+}\right.$and $\left.\mathrm{Cl}^{-}\right)$in the roots and leaves of rice [27]. 
In addition, $\mathrm{P}$ application increases $\mathrm{N}$ uptake efficiency under salinity conditions in corn, mainly due to the improvement in P availability in the root zone and its uptake [63].

Application of $\mathrm{P}$ fertilizer at all salinity levels increased both above- and underground plant parts. Our results confirm the previous findings of Belouchrani et al. [37] who reported that increased P rate stabilized the plant height in saline soil. In a similar study, Tang et al. [65] found that Maize biomass improved significantly (by twice) when the plants were subjected to a high rate of $\mathrm{P}$ application under salinity compared to a low rate of $\mathrm{P}$. $\mathrm{P}$ application under saline conditions and has positive effects on shoot and root biomass, root length, $\mathrm{P}$ concentration, and chlorophyll content in green beans $[35,66]$. Phosphorus reduces the harmful effects of salt by increasing the fresh weight of roots and the shoot lengths of barley [30].

\section{Materials and Methods}

\subsection{Experimental Site}

This research was conducted between May 2019 to July 2020 at an experimental farm of the National Institute of Agronomic Research (INRA) in Tadla, Morocco (latitude $=32.2^{\circ} \mathrm{N}$; $\mathrm{Y}=6.31^{\circ} \mathrm{W}$; altitude $=450 \mathrm{~m}$ ). The soil of the experimental site is classified as Chromic Luvisols [67]. The climate is arid with high rainfall variability. The average annual pluviometry is $286 \mathrm{~mm}$ and the average temperature $18^{\circ} \mathrm{C}$, with the highest in August, which often exceeds $45^{\circ} \mathrm{C}$ and the lowest in January which can range up to $-3^{\circ} \mathrm{C}$ (Figure 6).

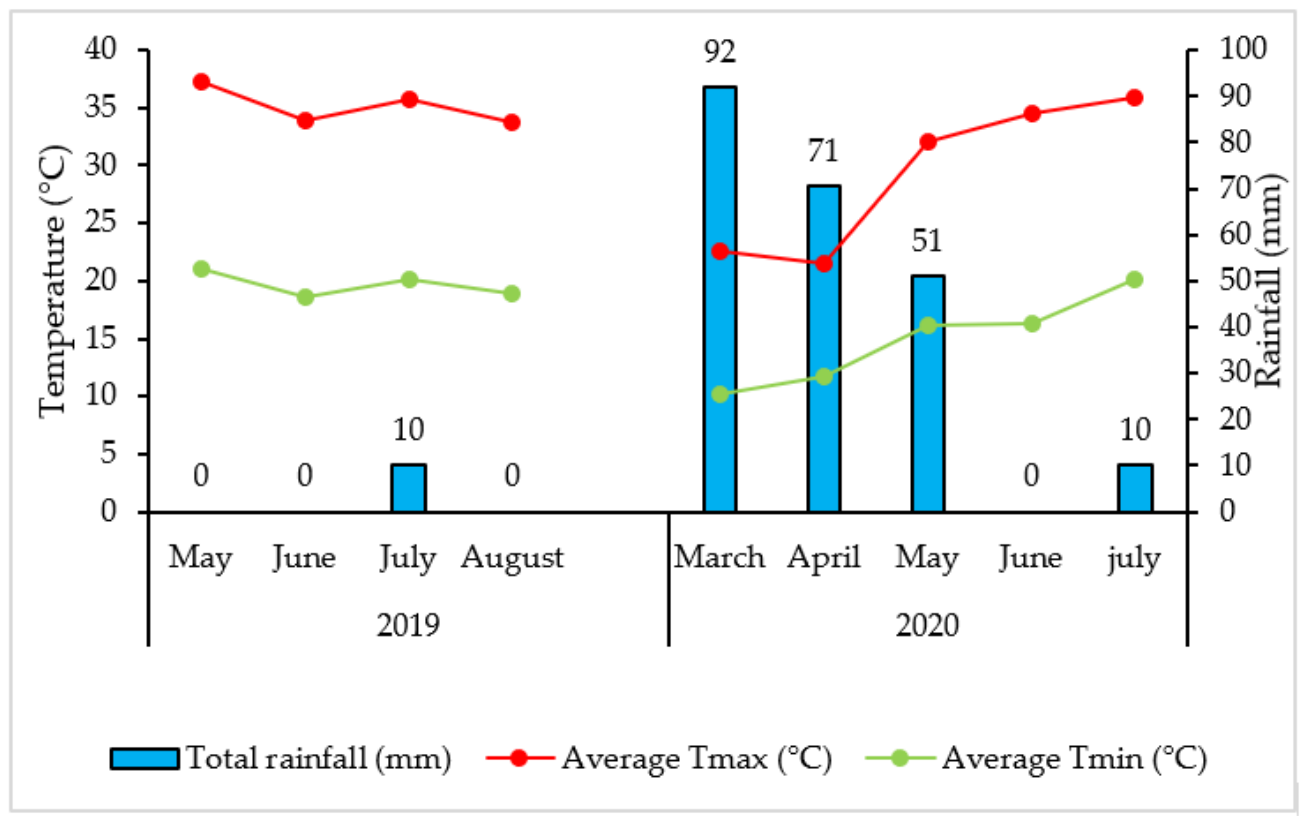

Figure 6. Temperature and rainfall during the experimental period in 2019 and 2020 in Tadla, Morocco.

\subsection{Initial Soil and Water Characteristics}

Before forage corn sowing. The sol analysis at two soil depths was performed following the protocol described by Jackson [68] (Table 2). The electrical conductivity of the soil was measured using the soil-saturated paste method with an EC meter (HI 9812, Hanna Instruments, Casablanca, Morocco). As the ECe values were relatively low (Table 3), the soil is non-saline [69].

Table 3. Initial soil characteristics in the experimental site Tadla, 2019.

\begin{tabular}{|c|c|c|c|c|c|c|c|c|c|c|c|}
\hline $\begin{array}{l}\text { Soil Depth } \\
\text { (cm) }\end{array}$ & $\begin{array}{l}\text { Clay } \\
(\%)\end{array}$ & $\begin{array}{l}\text { Silt } \\
(\%)\end{array}$ & $\begin{array}{c}\text { Sand } \\
(\%)\end{array}$ & $\begin{array}{l}\text { Soil } \\
\text { pH }\end{array}$ & $\underset{\text { Water }}{\mathrm{pH}}$ & $\mathrm{I} \mathrm{KCl}$ & $\begin{array}{c}\text { EC } \\
\left(\mathrm{d} S \cdot \mathrm{m}^{-1}\right)\end{array}$ & $\begin{array}{c}\text { Organic } \\
\text { Matter (\%) }\end{array}$ & $\begin{array}{l}\text { Total N (Kjeldahl) } \\
\left(\mathrm{g} \cdot \mathrm{kg}^{-1}\right)\end{array}$ & $\begin{array}{l}\mathrm{P}_{2} \mathrm{O}_{5} \text { (Olsen) } \\
\left(\mathrm{mg}^{\left.-k^{-1}\right)}\right.\end{array}$ & $\begin{array}{c}\left.\mathrm{K}_{2} \mathrm{O} \text { (Acetate of } \mathrm{Na}\right) \\
\left(\mathrm{mg}^{\left.-\mathrm{kg}^{-1}\right)}\right.\end{array}$ \\
\hline $0-20$ & 28.1 & 52.8 & 19.1 & 7.92 & 8.24 & 7.36 & 0.1 & 1.45 & 2.34 & 43 & 459 \\
\hline $20-40$ & 43.1 & 18.7 & 38.2 & 8.09 & 8.38 & 7.24 & 0.22 & 0.59 & 3.44 & 22 & 405 \\
\hline
\end{tabular}


Irrigation freshwater analysis is presented in Table 4 in terms of EC, $\mathrm{pH}$ cations and anions.

Table 4. Irrigation freshwater chemical analysis.

\begin{tabular}{ccccccccccc}
\hline \multirow{2}{*}{$\begin{array}{c}\mathrm{EC} \\
(\mathbf{d S} / \mathbf{m})\end{array}$} & $\mathbf{p H}$ & \multicolumn{4}{c}{ Cations (meq/L) } & \multicolumn{5}{c}{ Anions (meq/L) } \\
\cline { 2 - 11 } & & $\mathrm{Ca}^{2+}$ & $\mathbf{M g}^{2+}$ & $\mathbf{N a}^{+}$ & $\mathrm{K}^{+}$ & $\mathrm{Cl}^{-}$ & $\mathbf{S O}_{4}{ }^{2-}$ & $\mathbf{C O}_{3}{ }^{2-}$ & $\mathbf{H C O}_{3}{ }^{-}$ & $\mathbf{N O}_{3}{ }^{-}$ \\
\hline 0.7 & 7.4 & 2.4 & 3.9 & 2.290 & 0.001 & 2.25 & 0.54 & 1.2 & 4.3 & 0.12452 \\
\hline
\end{tabular}

\subsection{Experimental Design and Treatments}

The field experiment was conducted over an area of about $1000 \mathrm{~m}^{2}$ in a split-plot design with three replicates applying four salinity level irrigation water and three phosphorus fertilization rates. The tested salinity levels were freshwater with an EC value of $0.7 \mathrm{dS} \cdot \mathrm{m}^{-1}$ and three levels of saline water with an EC of 2,4 and $6 \mathrm{dS} \cdot \mathrm{m}^{-1}$. Salinity levels were achieved by adding salt $(\mathrm{NaCl})$ to freshwater. The $\mathrm{P}$ fertilization rate consisted of 105 (the recommended rate used by farmers), 126 (plus 20\%), and $150 \mathrm{~kg} \mathrm{P}_{2} \mathrm{O}_{5} \cdot \mathrm{ha}^{-1}$ (plus $40 \%$ of recommended rate). The area of each plot was $20 \mathrm{~m}^{2}(4 \mathrm{~m} \times 5 \mathrm{~m})$, and each consisted of six rows with a $75 \mathrm{~cm}$ interline. A $1 \mathrm{~m}$ distance was kept as buffer area between plots. For $\mathrm{P}$, triple superphosphate $\left(45 \%\right.$ of $\left.\mathrm{P}_{2} \mathrm{O}_{5}\right)$ was applied, which is commonly used in the region. Phosphorus fertilizer was incorporated into the soil before sowing during the soil preparation which consisted of a deep ploughing using disc plough followed by a superficial ploughing using cover crop. P fertilizer was applied during the superficial soil preparation.

Other fertilizer requirements were applied equally for all treatments through fertigation with a drip irrigation system using integrated drippers with a discharge of $2 \mathrm{~L} \cdot \mathrm{h}^{-1}$ and a distance of $40 \mathrm{~cm}$ between drippers. Irrigation with saline water started 35 days after planting, and the crop was irrigated daily until harvest (20 August 2019 for the first season and 15 July 2020 for the second season). The amount of irrigation matched with the amount of potential evapotranspiration. Saline irrigation solutions were prepared in a separate tank of $1 \mathrm{~m}^{3}$ before each irrigation and irrigation water EC was monitored using EC meter. Forage corn was sown on 10 May 2019 and harvested on 20 August 2019 for the first season, while in the second season, it was sown on 15 April 2020 and harvested on 15 July 2020. The recommended seed rate of 100,000 seeds per ha was used with an inter-row distance equal to $75 \mathrm{~cm}$ and inter-plant distance equal to $13 \mathrm{~cm}$. Thinning of plants (two per hole) was performed prior to the treatment application. The soil was supplemented with a total quantity of $162 \mathrm{~kg}$ of $\mathrm{N} \cdot \mathrm{ha}^{-1}$. About $42 \mathrm{~kg}^{-1}$ of $\mathrm{N}$ was applied at soil preparation using ammonium sulfate and $120 \mathrm{~kg} \mathrm{~N} \cdot \mathrm{ha}^{-1}$ using ammonium nitrate was applied through fertigation system during the growing period.

\subsection{Observations}

\subsubsection{Growth and Yield}

The dry matter yield was measured at harvest using the whole plot area $\left(20 \mathrm{~m}^{2}\right)$ and then extrapolated to $t \cdot h^{-1}$. Yield components, including root weight and length, plant height, shoot fresh weight and leaf number and area were determined using the values from six representative plants per plot. The sun-dried grain yield was measured at harvest using the half plot area $\left(10 \mathrm{~m}^{2}\right)$. The cobs harvested were sun-dried. Corn shelled and grain weight was measured one month after harvest of corn silage.

\subsubsection{Stomatal Conductance}

Stomatal conductance was measured using the SC-1 Leaf Porometer (Decagon Devices, Inc., Pullman, WA, USA). It was determined between $10 \mathrm{am}$ and $13 \mathrm{pm}$ on the upper leaf surface well exposed to sunlight. One measurement per plant was carried out for four plants per plot once for each season. 


\subsection{Statistical Analysis}

Statistical analysis was carried out using SPSS software version 17.0. A two-way analysis of variance (ANOVA) was used to assess the effects of both salinity and phosphorus rate monitored parameters. Before conducting the ANOVA, the normality of the data distribution was examined for dry matter and grain yield using the Shapiro-Wilk test. ANOVA combined over the season was performed as the season $\mathrm{x}$ treatment effect was not significant. The level of significance was set to $p<0.05$. The treatment mean differences were analyzed using Tukey's test $(p \leq 0.05)$.

Correlation and multivariate analysis were performed using the statistical programming language R 4.0.5. The "corrplot" package was used to display the Pearson correlation matrix values among variables, the level of significance was set to $p<0.05$. Principal component analysis (PCA) was performed using "ggplot2", "factoextra" and "FactoMineR" packages.

\section{Conclusions}

Due to increased salinization problem in the world in general and specifically in Morocco, practices such fertilization could be a judicious solution to alleviate the adverse effect of salinity on crop productivity. The findings of our study reveal that phosphorus supply has a positive effect on growth parameters and the yield of forage corn under saline conditions. Thus, it improves the tolerance to salinity. In the light of results obtained, and in order to achieve a satisfactory yield, it is recommended to apply a phosphorus rate of $126 \mathrm{~kg}$ of $\mathrm{P}_{2} \mathrm{O}_{5} \mathrm{ha}^{-1}$ under moderate salinity $\left(4 \mathrm{dS} \cdot \mathrm{m}^{-1}\right)$ and $150 \mathrm{~kg}$ of $\mathrm{P}_{2} \mathrm{O}_{5} \mathrm{ha}^{-1}$ under high salinity conditions $\left(6 \mathrm{dS} \cdot \mathrm{m}^{-1}\right)$.

Author Contributions: Conceptualization, R.C.-A. and A.B.; methodology, H.B.; software, H.B.; validation, B.B., R.C.-A. and A.B.; formal analysis, H.B.; investigation, H.B. and B.B.; resources, R.C.-A. and B.B.; data curation, A.H.; writing-original draft preparation, H.B., K.P.D. and A.H.; writing-review and editing, A.H., R.C.-A. and A.B.; visualization, A.H. and H.B.; supervision, R.C.-A. and A.B. and B.B.; project administration, R.C.-A.; funding acquisition, R.C.-A. All authors have read and agreed to the published version of the manuscript.

Funding: This research was funded by the OCP Foundation within AppHos Project AGR-CHO01/2017 with also by the financial and technical support of INRA Tadla, Morocco.

Institutional Review Board Statement: Not applicable.

Informed Consent Statement: Not applicable.

Data Availability Statement: Data is contained within the article.

Acknowledgments: The authors thank the OCP Foundation for financial support and the National Institute for Agronomic Research of Tadla Morocco (INRA) for supporting this study and providing research facilities and by financial support.

Conflicts of Interest: The authors declare no conflict of interest.

\section{References}

1. Machado, R.; Serralheiro, R. Soil Salinity: Effect on Vegetable Crop Growth. Management Practices to Prevent and Mitigate Soil Salinization. Horticulturae 2017, 3, 30. [CrossRef]

2. Jamil, A.; Riaz, S.; Ashraf, M.; Foolad, M.R. Gene Expression Profiling of Plants under Salt Stress. Crit. Rev. Plant Sci. 2011, 30, 435-458. [CrossRef]

3. Aragüés, R.; Urdanoz, V.; Çetin, M.; Kirda, C.; Daghari, H.; Ltifi, W.; Lahlou, M.; Douaik, A. Soil Salinity Related to Physical Soil Characteristics and Irrigation Management in Four Mediterranean Irrigation Districts. Agric. Water Manag. 2011, 98, 959-966. [CrossRef]

4. MEMECEE Rapport de Diagnostique de l'Etat de l'Environnement Au Maroc (Maroc: Ministère de l'Energie, Des Mines, de l'Eau et de l'Environnement, Chargé de l'Eau et de l'Environnement Département de l'Environnement). Available online: http:/ / www.Environnement.gov.Ma/PDFs/Rapport-Reem.Pdf2015 (accessed on 24 January 2021).

5. ORMVAT Office Régionale de Mise En Valeur Agricole de Tadla Morocco.Suivi des Paramètres Environnementaux" Campagne Fin d'Été. 2019. Available online: https:/ / ormva-tadla.ma/filieres/production-v\%C3\%A9g\%C3\%A9tale (accessed on 20 January 2021). 
6. Tester, M.; Davenport, R. Na ${ }^{+}$Tolerance and $\mathrm{Na}^{+}$Transport in Higher Plants. Ann. Bot. 2003, 91, 503-527. [CrossRef]

7. Ashraf, M.; Foolad, M.R. Roles of Glycine Betaine and Proline in Improving Plant Abiotic Stress Resistance. Environ. Exp. Bot. 2007, 59, 206-216. [CrossRef]

8. Liang, W.; Ma, X.; Wan, P.; Liu, L. Plant Salt-Tolerance Mechanism: A Review. Biochem. Biophys. Res. Commun. 2018, 495, $286-291$. [CrossRef] [PubMed]

9. Zörb, C.; Geilfus, C.-M.; Dietz, K.-J. Salinity and Crop Yield. Plant Biol. 2019, 21, 31-38. [CrossRef]

10. Zhang, J.-L.; Shi, H. Physiological and Molecular Mechanisms of Plant Salt Tolerance. Photosynth. Res. 2013, 115, 1-22. [CrossRef]

11. Munns, R.; Tester, M. Mechanisms of Salinity Tolerance. Annu. Rev. Plant Biol. 2008, 59, 651-681. [CrossRef]

12. Ortas, I.; Ra, M. Do Mycorrhizal Fungi Enable Plants to Cope with Abiotic Stresses by Overcoming the Detrimental Effects of Salinity and Improving Drought Tolerance? In Symbiotic Soil Microorganisms; Springer Publishing Company, Inc.: New York, NY, USA, 2021; pp. 391-428.

13. Flowers, T.J.; Colmer, T.D. Salinity Tolerance in Halophytes. New Phytol. 2008, 179, 945-963. [CrossRef]

14. Azizian, A.; Sepaskhah, A.R. Maize Response to Water, Salinity and Nitrogen Levels: Yield-Water Relation, Water-Use Efficiency and Water Uptake Reduction Function. Int. J. Plant Prod. 2014, 32, 183-214.

15. Rhoades, J.D.; Kandiah, A.; Mashali, A.M. The Use of Saline Waters for Crop Production; FAO Irrigation and Drainage Paper; Food and Agriculture Organization of the United Nations: Rome, Italy, 1992; ISBN 978-92-5-103237-4.

16. Doorenbos, J.; Kassam, A.H. Crop Yield Response to Water. Yield Response Water 1979, 33, 257.

17. Wang, X.; Yang, J.; Liu, G.; Yao, R.; Yu, S. Impact of Irrigation Volume and Water Salinity on Winter Wheat Productivity and Soil Salinity Distribution. Agric. Water Manag. 2015, 149, 44-54. [CrossRef]

18. Xue, J.; Ren, L. Conjunctive Use of Saline and Non-Saline Water in an Irrigation District of the Yellow River Basin: Regional Conjunctive Use of Saline and Non-Saline Water for Irrigation. Irrig. Drain. 2017, 66, 147-162. [CrossRef]

19. Hopmans, J.W.; Qureshi, A.S.; Kisekka, I.; Munns, R.; Grattan, S.R.; Rengasamy, P.; Ben-Gal, A.; Assouline, S.; Javaux, M.; Minhas, P.S.; et al. Critical Knowledge Gaps and Research Priorities in Global Soil Salinity. In Advances in Agronomy; Elsevier: Amsterdam, The Netherlands, 2021; Volume 169, pp. 1-191. ISBN 978-0-12-824590-3.

20. Soliman, M.S.; Shalabi, H.G.; Campbell, W.F. Interaction of Salinity, Nitrogen, and Phosphorus Fertilization on Wheat. J. Plant Nutr. 1994, 17, 1163-1173. [CrossRef]

21. Champagnol, F. Relationships between Phosphate Nutrition of Plants and Salt Toxicity. Phosphorus Agric. 1979, $76,35-43$.

22. Raghothama, K.G.; Karthikeyan, A.S. Phosphate Acquisition. Plant Soil 2005, 274, 37. [CrossRef]

23. Cerda, A.; Bingham, F.T.; Hoffman, G.J. Interactive Effect of Salinity and Phosphorus on Sesame. Soil Sci. Soc. Am. J. 1977, 41, 915-918. [CrossRef]

24. Awad, A.S.; Edwards, D.G.; Campbell, L.C. Phosphorus Enhancement of Salt Tolerance of Tomato. Crop Sci. 1990, 30, 123-128. [CrossRef]

25. Kalifa, A.; Barthakur, N.N.; Donnelly, D.J. Phosphorus Reduces Salinity Stress in Micropropated Potato. Am. J. Potato Res. 2000, 77, 179-182. [CrossRef]

26. Kaya, C.; Higgs, D.; Kirnak, H. The Effects of High Salinity (Nacl) and Supplementary Phosphorus and Potassium on Physiology and Nutrition Development of Spinach. Bulg. J. Plant Physiol. 2001, 27, 47-59.

27. Naheed, G.; Shahbaz, M.; Akram, N.A. Interactive Effect of Rooting Medium Application of Phosphorus and NaCl on Plant Biomass and Mineral Nutrients of Rice (Oryza sativa). Pak. J. Bot. 2008, 40, 1601-1608.

28. Çimrin, K.M.; Türkmen, Ö.; Turan, M.; Tuncer, B. Phosphorus and Humic Acid Application Alleviate Salinity Stress of Pepper Seedling. Afr. J. Biotechnol. 2010, 936, 5845-5851.

29. Shahriaripour, R.; Tajabadi Pour, A.; Mozaffari, V. Effects of Salinity and Soil Phosphorus Application on Growth and Chemical Composition of Pistachio Seedlings. Commun. Soil Sci. Plant Anal. 2011, 42, 144-158. [CrossRef]

30. Khosh Kholgh Sima, N.A.; Ahmad, S.T.; Alitabar, R.A.; Mottaghi, A.; Pessarakli, M. Interactive Effects of Salinity and Phosphorus Nutrition on Physiological Responses of Two Barley Species. J. Plant Nutr. 2012, 35, 1411-1428. [CrossRef]

31. Abd El-Hamed, E.; Metwally, S.; Matar, M.; Yousef, N. Impact of Phosphorus Fertilization in Alleviating the Adverse Effects of Salinity on Wheat Grown on Different Soil Types. Acta Agron. Hung. 2012, 60, 265-281. [CrossRef]

32. Abu-Romman, S.; Suwwan, M.; Al-Ramamneh, E.A.-D. Alleviation of Salt Stress by Phosphorus in Cucumber Microshoots Grown on Rooting Medium. World Appl. Sci. J. 2013, 22, 186-191.

33. Zribi, O.T.; Houmani, H.; Kouas, S.; Slama, I.; Ksouri, R.; Abdelly, C. Comparative Study of the Interactive Effects of Salinity and Phosphorus Availability in Wild (Hordeum Maritimum) and Cultivated Barley (H. Vulgare). J. Plant Growth Regul. 2014, 33, 860-870. [CrossRef]

34. Bargaz, A.; Nassar, R.M.A.; Rady, M.M.; Gaballah, M.S.; Thompson, S.M.; Brestic, M.; Schmidhalter, U.; Abdelhamid, M.T. Improved Salinity Tolerance by Phosphorus Fertilizer in Two Phaseolus Vulgaris Recombinant Inbred Lines Contrasting in Their P-Efficiency. J. Agron. Crop Sci. 2016, 202, 497-507. [CrossRef]

35. Gulmezoglu, N. The Interactive Effects of Phosphorus and Salt on Growth, Water Potenital and Phosphorus Uptake in Green Beans. Appl. Ecol. Environ. Res. 2017, 15, 1831-1842. [CrossRef]

36. Bouras, H.; Bouaziz, A.; Bouazzama, B.; Hirich, A.; Choukr-Allah, R. How Phosphorus Fertilization Alleviates the Effect of Salinity on Sugar Beet (Beta vulgaris L.) Productivity and Quality. Agronomy 2021, 11, 1491. [CrossRef] 
37. Belouchrani, A.S.; Latati, M.; Ounane, S.M.; Drouiche, N.; Lounici, H. Study of the Interaction Salinity: Phosphorus Fertilization on Sorghum. J. Plant Growth Regul. 2020, 39, 1205-1210. [CrossRef]

38. Malik, R.S.; Gupta, A.P.; Haneklaus, S.; El Bassam, N. Role of Phosphorus (P-32) in Inducing Salt Tolerance in Sunflower. Landbauforsch. Volkenrode 1999, 49, 169-176.

39. Betzen, B.M.; Smart, C.M.; Maricle, K.L.; MariCle, B.R. Effects of Increasing Salinity on Photosynthesis and Plant Water Potential in Kansas Salt Marsh Species. Trans. Kans. Acad. Sci. 2019, 122, 49-58. [CrossRef]

40. Stepien, P.; Johnson, G.N. Contrasting Responses of Photosynthesis to Salt Stress in the Glycophyte Arabidopsis and the Halophyte Thellungiella: Role of the Plastid Terminal Oxidase as an Alternative Electron Sink. Plant Physiol. 2009, 149, 1154-1165. [CrossRef]

41. Wani, A.S.; Ahmad, A.; Hayat, S.; Tahir, I. Epibrassinolide and Proline Alleviate the Photosynthetic and Yield Inhibition under Salt Stress by Acting on Antioxidant System in Mustard. Plant Physiol. Biochem. 2019, 135, 385-394. [CrossRef] [PubMed]

42. Maia, F.M.A.; Costa, A.C.; de Castro, J.N.; Megguer, C.A.; Soares, F.A.L. Photosynthesis and Water Relations of Sunflower Cultivars under Salinity Conditions. Afr. J. Agric. Res. 2016, 11, 2817-2824.

43. Yuan, C.; Feng, S.; Wang, J.; Huo, Z.; Ji, Q. Effects of Irrigation Water Salinity on Soil Salt Content Distribution, Soil Physical Properties and Water Use Efficiency of Maize for Seed Production in Arid Northwest China. Int. J. Agric. Biol. Eng. 2018, 11, 137-145. [CrossRef]

44. Hessini, K.; Issaoui, K.; Ferchichi, S.; Saif, T.; Abdelly, C.; Siddique, K.H.M.; Cruz, C. Interactive Effects of Salinity and Nitrogen Forms on Plant Growth, Photosynthesis and Osmotic Adjustment in Maize. Plant Physiol. Biochem. 2019, 139, 171-178. [CrossRef]

45. Liu, X.; Feike, T.; Chen, S.; Shao, L.; Sun, H.; Zhang, X. Effects of Saline Irrigation on Soil Salt Accumulation and Grain Yield in the Winter Wheat-Summer Maize Double Cropping System in the Low Plain of North China. J. Integr. Agric. 2016, 15, 2886-2898. [CrossRef]

46. Brugnoli, E.; Lauteri, M. Effects of Salinity on Stomatal Conductance, Photosynthetic Capacity, and Carbon Isotope Discrimination of Salt-Tolerant (Gossypium hirsutum L.) and Salt-Sensitive (Phaseolus vulgaris L.) C3 Non-Halophytes. Plant Physiol. 1991, 95, 628-635. [CrossRef] [PubMed]

47. Zhu, X.; Cao, Q.; Sun, L.; Yang, X.; Yang, W.; Zhang, H. Stomatal Conductance and Morphology of Arbuscular Mycorrhizal Wheat Plants Response to Elevated $\mathrm{CO}_{2}$ and $\mathrm{NaCl}$ Stress. Front. Plant Sci. 2018, 9, 1363. [CrossRef] [PubMed]

48. Ben-Asher, J.; Tsuyuki, I.; Bravdo, B.-A.; Sagih, M. Irrigation of Grapevines with Saline Water: I. Leaf Area Index, Stomatal Conductance, Transpiration and Photosynthesis. Agric. Water Manag. 2006, 83, 13-21. [CrossRef]

49. Farooq, M.; Hussain, M.; Wakeel, A.; Siddique, K.H.M. Salt Stress in Maize: Effects, Resistance Mechanisms, and Management. A Review. Agron. Sustain. Dev. 2015, 35, 461-481. [CrossRef]

50. Lohaus, G.; Hussmann, M.; Pennewiss, K.; Schneider, H.; Zhu, J.; Sattelmacher, B. Solute Balance of a Maize (Zea mays L.) Source Leaf as Affected by Salt Treatment with Special Emphasis on Phloem Retranslocation and Ion Leaching. J. Exp. Bot. 2000, 51, 1721-1732. [CrossRef]

51. Kaya, C.; Ashraf, M.; Dikilitas, M.; Tuna, A. Alleviation of Salt Stress-Induced Adverse Effects on Maize Plants by Exogenous Application of Indoleacetic Acid (IAA) and Inorganic Nutrients-A Field Trial. Aust. J. Crop Sci. 2013, 7, $249-254$.

52. Fortmeier, R.; Schubert, S. Salt Tolerance of Maize (Zea mays L.): The Role of Sodium Exclusion. Plant Cell Environ. 1995, 18, 1041-1047. [CrossRef]

53. Schubert, S.; Neubert, A.; Schierholt, A.; Sümer, A.; Zörb, C. Development of Salt-Resistant Maize Hybrids: The Combination of Physiological Strategies Using Conventional Breeding Methods. Plant Sci. 2009, 177, 196-202. [CrossRef]

54. Hussein, M.; Balbaa, L.; Gaballah, M. Salicylic Acid and Salinity Effects on Growth of Maize Plants. Res. J. Agric. Biol. Sci. 2007, 3, 321-328.

55. Singh, P.K.; Shahi, S.K.; Singh, A.P. Effects of Salt Stress on Physico-Chemical Changes in Maize (Zea mays L.) Plants in Response to Salicylic Acid. Indian J. Plant Sci. 2015, 4, 69-77.

56. Alberico, G.J.; Cramer, G.R. Is the Salt Tolerance of Maize Related to Sodium Exclusion? I. Preliminary Screening of Seven Cultivars. J. Plant Nutr. 1993, 16, 2289-2303. [CrossRef]

57. Szalai, G.; Janda, T. Effect of Salt Stress on the Salicylic Acid Synthesis in Young Maize (Zea mays L.) Plants. J. Agron. Crop Sci. 2009, 195, 165-171. [CrossRef]

58. Kurth, E.; Cramer, G.R.; Läuchli, A.; Epstein, E. Effects of $\mathrm{NaCl}$ and $\mathrm{CaCl}_{2}$ on Cell Enlargement and Cell Production in Cotton Roots. Plant Physiol. 1986, 82, 1102-1106. [CrossRef] [PubMed]

59. Mari, A.H.; Rajpar, I.; Tunio, S.D. Effect of Salinity on Growth and Yield of Sugar Beet (Beta vulgaris 1.) under Lower Sindh Environment. Pak. J. Agric. Agric. Eng. Vet. Sci. 2017, 33, 153-162.

60. Ghazi, N.; Al-Karaki, R. Barley Response to Salt Stress at Varied Levels of Phosphorus. J. Plant Nutr. 1997, 20, $1635-1643$.

61. Jahan, M.N.; Barua, S.; Ali, H.; Ali, M.N.; Chowdhury, M.S.H.; Hasan, M.M.; Ferdous, T.; Eti, F.S.; Khayer, A.; Hossen, K. Effects of Phosphorus Fertilization on Hybrid Varieties of Mungbean [Vigna radiata (L.) Wilczek] in a Salinity Prone Area of the Subtropics. Acta Agrobot. 2020, 73, 7338. [CrossRef]

62. Sadji-Ait Kaci, H. Interactive Effects of Salinity and Two Phosphorus Fertilizers on Growth and Grain Yield of Cicer arietinum L. Section B Soil and Plant Science. Acta Agric. Scand. 2017, 67, 208-216. [CrossRef]

63. Alzubaidi, A.; Aljanabi, A.S.; Al-Rawi, A. Interaction between Nitrogen and Phosphorus Fertilizers and Soil Salinity and Its Effect on Growth and Ionic Composition of Corn (Zea mays L.). In Genetic Aspects of Plant Mineral Nutrition; El Bassam, N., Dambroth, M., Loughman, B.C., Eds.; Springer: Dordrecht, The Netherlands, 1990; pp. 195-202. ISBN 978-94-010-7421-6. 
64. Plaut, Z.; Grieve, C.M. Photosynthesis of Salt-Stressed Maize as Influenced by Ca:Na Ratios in the Nutrient Solution. Plant Soil 1988, 105, 283-286. [CrossRef]

65. Tang, H.; Niu, L.; Wei, J.; Chen, X.; Chen, Y. Phosphorus limitation improved salt tolerance in maize through tissue mass density increase, osmolytes accumulation, and $\mathrm{Na}^{+}$uptake inhibition. Front. Plant Sci. 2019, 10, 856. [CrossRef]

66. Qadar, A. Alleviation of Sodicity Stress on Rice Genotypes by Phosphorus Fertilization. Plant Soil. 1998, 203, 269-277. [CrossRef]

67. Badraoui, M.; Agbani, M.; Soudi, B. Evolution de La Qualité Des Sols Sous Mise En Valeur Intensive Au Maroc. Sémin. Intensif. Agric. Qual. Sols Eaux Rabat Maroc 2000, 2-3. Available online: https://www.vulgarisation.net/intensificationagricole/03 -badraoui.pdf (accessed on 23 November 2021).

68. Jackson, M.L. Soil Chemical Analysis: Advanced Course; UW-Madison Libraries Parallel Press: Madison, WI, USA, 2005.

69. Dahnke, W.C.; Whitney, D.A. Recommended Chemical Soil Test Procedures. North Cent. Reg. Publ. 1988, $221,18-34$. 